\title{
Growth dynamics and the proximate biochemical composition and fatty acid profile of the heterotrophically grown diatom Cyclotella cryptica
}

\author{
Stephen L. Pahl • David M. Lewis • Feng Chen • \\ Keith D. King
}

Received: 13 August 2008 /Revised and accepted: 25 March 2009/Published online: 22 April 2009

(C) Springer Science + Business Media B.V. 2009

\begin{abstract}
To investigate the nutritional value of the diatom Cyclotella cryptica as an alternative feed for aquaculture, its heterotrophic growth characteristics were studied. First, the proximate biochemical composition and fatty acid profiles were studied under a controlled heterotrophic growth condition. The approximate total ash, carbohydrate, lipid, and protein content were $245 \mathrm{mg} \mathrm{g}^{-1}$ (dry weight), $360 \mathrm{mg} \mathrm{g}^{-1}$, $165 \mathrm{mg} \mathrm{g}^{-1}$ and $260 \mathrm{mg} \mathrm{g}^{-1}$, respectively. Polyunsaturated fatty acids accounted for $24.5,31.3,45.1$ and $17.3 \%$ of the total lipids in the phospholipid, sterol, free fatty acid and triglyceride classes. Secondly, the effect of aeration and agitation rates on the specific growth rate of $C$. cryptica under heterotrophic conditions was studied. The maximum specific growth rate was not significantly affected $(P>0.05)$ by the rate of agitation within the range of 100 to $160 \mathrm{rpm}$, but it was significantly affected $(P>0.05)$ by the rate of aeration. Optimal growth occurred when the aeration rate was within the range of 0.44 to $1.07 \mathrm{v} / \mathrm{v} / \mathrm{min}$. Viability measurements throughout the growth period showed that the $C$. cryptica cells remained viable in spite of the varied cultivation conditions. Hydrodynamic forces are an important parameter within biological systems, and optimisation is crucial for the successful scale-up of microalgal cultivation systems. Whilst the investigation
\end{abstract}

\footnotetext{
S. L. Pahl $\cdot$ D. M. Lewis $(\bowtie) \cdot$ K. D. King

School of Chemical Engineering, The University of Adelaide, Adelaide SA 5005, Australia

e-mail: david.lewis@adelaide.edu.au

URL: www.chemeng.adelaide.edu.au/staff/dlewis01.html

F. Chen

School of Biological Sciences,

The University of Hong Kong,

Pokfulam Road,

Hong Kong, People's Republic of China
}

was preliminary in nature, the information gained in this study will be useful for the continual development of an alternative and cost-effective feed for bivalve spat rations.

Keywords Ash · Carbohydrate · Lipid · Mixing · Protein . PUFAs · Bacillariophyta

\section{Introduction}

There is a growing body of evidence that indicates the importance of polyunsaturated fatty acids (PUFAs) in human diets. PUFAs have specific physiological functions, and clinical studies have shown that an increase in consumption of the essential fatty acids, eicosapentaenoic acid (EPA, 20:5 n-3) and docosahexaenoic acid (DHA, 22:6 n-3), can result in improved general health and wellbeing. At present, these essential fatty acids are largely obtained through the consumption of seafood. However, many fish stocks are currently exploited above the maximum sustainable level, and many species could be vulnerable to extinction if current practices are maintained. In 2007, the Food and Agriculture Organisation of the United Nations reported that approximately $75 \%$ of the native fish stocks were fully exploited, overexploited, depleted or recovering from depletion (FAO Fisheries and Aquaculture Department 2007).

It has been widely suggested that the increased demand for seafood may be met by the expanding aquaculture industry. However, despite significant investments to date, the consistent supply of highly nutritious live microalgae remains a major 'bottleneck' and can affect the productivity and profitability of many commercial hatchery and nursery operations. Furthermore, the cultivation of microalgae is likely to remain a vital process within most aquaculture 
facilities as microalgae are the biological starting point for energy flow through aquatic ecosystems (De Pauw et al. 1984), and live microalgae are an essential feed source for molluscs, crustaceans and fish species, for at least part of their life cycle.

The nutritional value of the microalgal biomass depends on several physiological and biochemical attributes including microalgae size and shape, digestibility, non-toxicity and biochemical composition. Furthermore, the nutritional value of the microalgal biomass should match the nutritional requirements of the target organism (Webb and Chu 1983; Brown et al. 1989). The biochemical composition of microalgae is influenced by environmental conditions (light, temperature, salinity, $\mathrm{pH}$, aeration), nutritional factors (sources and availability) and culture age (Brown et al. 1989; Dunstan et al. 1992; Renaud and Parry 1994).

Traditional microalgae cultivation techniques, which rely on photosynthetic microalgae (grown in outdoor ponds or indoors under artificial lights), are generally expensive due to the relatively low biomass concentrations achieved, large operating costs, culture inefficiencies and unexplained crashes. It has been estimated that microalgal production costs can be as high as US\$ $600 \mathrm{~kg}^{-1}$ (Borowitzka 1997). Several reports including Gladue and Maxey (1994), Duerr et al. (1998), Heasman et al. (2002), Brown (2002) and Harel et al. (2002) have outlined that heterotrophically grown microalgal biomass is potentially a cost-effective alternative. The advantages to the use of heterotrophically grown microalgal biomass have previously been reviewed (Gladue and Maxey 1994; Chen 1996; Wen and Chen 2003). However, oxygen is frequently a limiting factor during the heterotrophic cultivation of microalgae (Beherns 2005), although this limitation is often preventable by adequate mixing.

Mixing affects the hydrodynamic conditions and is a critical parameter within biological systems and is important to: (1) prevent cell sedimentation; (2) prevent the formation of environmental, nutritional and gaseous gradients, thereby reducing boundary layers and improving mass and energy transfer rates; and (3) move cells through optical gradients, thereby varying the light regime (quantity and quality of light and frequency of the light/dark cycles) experienced by the microalgae cells (phototrophic and mixotrophic growth modes only).

Mixing can be accomplished via mechanical agitation, aeration or a combination of both. Mechanical agitation, through the use of impellers and baffles, often provides sufficient mixing (Beherns 2005); however, aeration is frequently required to satisfy the oxygen demand associated with the high cell densities achieved during heterotrophic cultivation. Unfortunately, excessive mixing may generate high shear conditions, which can lead to impaired cell growth, cell damage and eventually cell death. The tolerance to shear stresses and turbulence is speciesdependent and rates of shear are influenced by the rate and method of mixing, geometry of vessel, vessel surface, nutrient composition and cell concentration.

The aim of the present work is to investigate the heterotrophic growth characteristics and nutritional value of the diatom Cyclotella cryptica. This species is capable of heterotrophic growth (Hellebust 1971; White 1974; Gladue and Maxey 1994), has previously been used within the aquaculture industry (Loosanoff and Davis 1963; Laing and Millican 1992) and has been recommended as a species worthy of further investigation. The work presented in this paper details the proximate biochemical composition and fatty acid profile of $C$. cryptica under a controlled heterotrophic growth condition. Although this species is known to grow heterotrophically and has previously been used in aquaculture, its proximate biochemical composition and the fatty acid distribution under heterotrophic conditions have never been reported. The present paper also examines the individual effects of agitation and aeration rates on the specific growth rate of the diatom C. cryptica when cultivated heterotrophically.

\section{Materials and methods}

The diatom Cyclotella cryptica (UTEX 1269) was cultured heterotrophically in a modification of SK medium reported by Gladue and Maxey (1994). The modified medium used during the investigation into the proximate biochemical and fatty acid profile consisted of (per litre) $27.2 \mathrm{~g}$ synthetic sea salt (Taikong Corp., Taipei, Taiwan), $2.17 \mathrm{~g} \mathrm{MgSO}_{4} \cdot 7 \mathrm{H}_{2} \mathrm{O}$, $1.6 \mathrm{~g}$ tryptone, $917 \mathrm{mg} \mathrm{NaNO} 3,892 \mathrm{~g}$ Tris buffer, $800 \mathrm{mg}$ yeast extract, $50.5 \mathrm{mg} \mathrm{KK_{2 }} \mathrm{PO}_{4}, 34 \mathrm{mg} \mathrm{H}_{3} \mathrm{BO}_{3}, 20 \mathrm{mg}$ $\mathrm{FeSO}_{4} \cdot 7 \mathrm{H}_{2} \mathrm{O}, 15 \mathrm{mg} \mathrm{NaH} \mathrm{PO}_{4} \cdot 2 \mathrm{H}_{2} \mathrm{O}, 6 \mathrm{mg}$ thiamine $\cdot \mathrm{HCl}$, $5 \mathrm{mg} \mathrm{Na} 2$ EDTA, $4.3 \mathrm{mg} \mathrm{MnCl} \cdot 4 \mathrm{H}_{2} \mathrm{O}, 0.3 \mathrm{mg}$ vitamin $\mathrm{B}_{12}$, $0.3 \mathrm{mg}$ biotin, $0.3 \mathrm{mg} \mathrm{ZnCl}_{2}, 0.26 \mathrm{mg} \mathrm{NiSO}_{4} \cdot 6 \mathrm{H}_{2} \mathrm{O}$, $0.13 \mathrm{mg} \mathrm{CoCl} \mathrm{Cl}_{2} \cdot 6 \mathrm{H}_{2} \mathrm{O}, 0.03 \mathrm{mg} \mathrm{Na} \mathrm{MoO}_{4} \cdot 2 \mathrm{H}_{2} \mathrm{O}$, $0.017 \mathrm{mg} \mathrm{Na} \mathrm{SeO}_{3}$ and $0.01 \mathrm{mg} \mathrm{CuSO}_{4} \cdot 5 \mathrm{H}_{2} \mathrm{O}$ and was supplemented with $10 \mathrm{~g} \mathrm{~L}^{-1}$ glucose and $480 \mathrm{mg} \mathrm{L}^{-1}$ $\mathrm{Na}_{2} \mathrm{SiO}_{3} \cdot 5 \mathrm{H}_{2} \mathrm{O}$. The $\mathrm{pH}$ of the medium was adjusted to 7.5 prior to autoclaving at $121^{\circ} \mathrm{C}$ for $20 \mathrm{~min}$. The medium used during the investigation of the effects of agitation and aeration was the same as above, with the following exceptions: $6.8 \mathrm{~g}$ synthetic sea salt and the omission of the Tris buffer, tryptone and yeast extract.

\section{Cultivation systems}

Three different cultivation systems were investigated: $250 \mathrm{~mL}$ Erlenmeyer flasks containing $100 \mathrm{~mL}$ sterilised medium were incubated on orbital shakers at five mixing rates $(100,115,130,145$ and $160 \mathrm{rpm}) ; 500 \mathrm{~mL}$ Schott 
bottles containing $400 \mathrm{~mL}$ sterilised medium were incubated at three aeration rates $(0.28,0.44$ and $1.07 \mathrm{v} / \mathrm{v} / \mathrm{min})$; and $19 \mathrm{~L}$ carboys containing $16 \mathrm{~L}$ sterilised medium were incubated with an aeration rate of $0.25 \mathrm{v} / \mathrm{v} / \mathrm{min}$. All cultivation systems were inoculated with $6-10 \%$ exponentially growing culture and were incubated at $25^{\circ} \mathrm{C}$ in darkness. Air (if supplied) was filtered through $0.22-\mu \mathrm{m}$ filters.

Determination of biomass, growth rate and viability

The biomass concentration was determined spectrophotometrically from the culture absorbance measured at $675 \mathrm{~nm}$ and was compared to a correlation curve that was previously developed (Pahl, unpublished data). At the termination of the experiment, the biomass was harvested by centrifugation (15,700 $\mathrm{rcf}$ [relative centrifugal force] for $10 \mathrm{~min}$ ), rinsed twice with purified water, dried in a freeze drier and stored at $-18^{\circ} \mathrm{C}$ prior to analysis. The specific growth rate was determined by plotting the natural logarithm of culture dry weight against time. Readings within the exponential phase were then used to obtain the maximum specific growth rate by linear regression. Cell viability was determined by the method reported by Crippen and Perrier (1974).

\section{Determination of nutrient status}

Throughout the cultivation, samples of the culture suspension were centrifuged $(15,700 \mathrm{rcf}$ for $10 \mathrm{~min})$ and the supernatant stored at $4{ }^{\circ} \mathrm{C}$ until analysed. The residual glucose concentration in the media was determined based on the dinitrosalicylic acid assay (Miller 1959). A 1-mL sample and 5-mL dinitrosalicylic acid reagent was heated to $95^{\circ} \mathrm{C}$ for $10 \mathrm{~min}$ in tightly capped tubes. Tubes were allowed to cool to room temperature and absorbance at $570 \mathrm{~nm}$ was measured and compared to known glucose standards. The residual sodium metasilicate concentration in the media was determined based on the method reported by Hansen and Koroleff (1999).

Determination of proximate biochemical composition and fatty acid profile

Ash was determined gravimetrically using a method based on ASTM E-1755 (1995). Freeze-dried biomass was heated to $575^{\circ} \mathrm{C}$ and held until constant weight in a muffle furnace. Carbohydrate content was determined using the phenol-sulphuric acid method with the absorbance measured at $485 \mathrm{~nm}$ following extraction with $0.5 \mathrm{M}$ sulphuric acid at $90^{\circ} \mathrm{C}$ for $60 \mathrm{~min}$ (Dubois et al. 1956). Total nitrogen was determined with a Leco TruSpec CHN analyser (Leco Australia, Castle Hill, NSW,
Australia), and crude protein calculated by total nitrogen multiplied by a conversion factor of 6.25 (Dorsey et al. 1978). Total lipids were extracted with $6 \mathrm{~mL}$ of chloroform/methanol $(2: 1, v / v)$ and $1.5 \mathrm{~mL}$ saline. Lipid extracts were evaporated to dryness in a vacuum concentrator at $60^{\circ} \mathrm{C}$ prior to being weighed.

The lipids were separated by thin layer chromatography (TLC) into phospholipid, triglyceride, cholesterol ester, free fatty acid and sterol classes on silica gel plates. The solvent system for TLC was petroleum spirit/diethyl ether/glacial acetic acid $(180: 30: 2, v / v / v)$. Lipid classes were visualised with fluorescein 5-isothiocyanate against TLC standard 185 (Nu-Chek Prep, Elysian, USA). All solvents contained the antioxidant butylated hydroxy anisole at $0.005 \%(w / v)$. Lipid fractions were transesterified by methanolysis $(1 \%$ $\mathrm{H}_{2} \mathrm{SO}_{4}$ in methanol) for $3 \mathrm{~h}$ at $70^{\circ} \mathrm{C}$ (Blank et al. 2002). After cooling, the resulting fatty acid methyl esters (FAMEs) were extracted with $n$-heptane and dried over anhydrous sodium sulphate. The FAMEs were analysed with a Hewlett-Packard 6890 gas chromatograph equipped with a flame ionisation detector and a BPX-70 (50 m× $0.32 \mathrm{~mm}$ ID $\times 0.25 \mu \mathrm{m}$ film thickness) capillary column (SGE Pty Ltd, Australia). Helium was used as the carrier gas with a column flow rate of $34 \mathrm{~cm} / \mathrm{s}$. The injector and detector temperatures were set at $250^{\circ} \mathrm{C}$ and $300^{\circ} \mathrm{C}$, respectively. Samples $(5 \mu \mathrm{L})$ were injected with a split ratio of $20: 1$. The initial oven temperature was $140^{\circ} \mathrm{C}$ and programmed to rise to $220^{\circ} \mathrm{C}$ at $5^{\circ} \mathrm{C} \mathrm{min}{ }^{-1}$, held for $1 \mathrm{~min}$, followed by a further rise to $260^{\circ} \mathrm{C}$ at $20^{\circ} \mathrm{C} \mathrm{min}^{-1}$. FAMEs were identified by comparison of retention times to authentic lipid standards (Nu-Chek Prep, USA).

\section{Statistical analysis}

Significant differences between experimental conditions were detected by means of one-way analysis of variance (ANOVA), followed by pairwise comparisons using

Table 1 Proximate biochemical composition (percentage of dry weight) of Cyclotella cryptica biomass ( $n=2$, unless otherwise specified)

\begin{tabular}{lll}
\hline Mode of growth & $\begin{array}{l}\text { Heterotrophic } \\
\text { (present study) }\end{array}$ & $\begin{array}{l}\text { Photoautotrophic } \\
\text { (Darley 1977) }\end{array}$ \\
\hline Protein & $26.0 \pm 0.2$ & 31 \\
Carbohydrate & $35.8 \pm 1.2$ & 26 \\
Lipid & $16.5^{\mathrm{a}}$ & 12 \\
Ash & $24.6 \pm 0.2$ & n.r. \\
\hline
\end{tabular}

Biomass cultivated in $250 \mathrm{~mL}$ Erlenmeyer flasks containing $100 \mathrm{~mL}$ media and agitated on an orbital mixer at $100 \mathrm{rpm}$

n.r. not recorded

${ }^{\mathrm{a}} n=1$ 
Table 2 Fatty acid composition (percentage of individual lipid class) of Cyclotella cryptica biomass grown under heterotrophic conditions $(n=1)$

\begin{tabular}{|c|c|c|c|c|}
\hline & Phospholipid & Sterol & $\begin{array}{l}\text { Free fatty } \\
\text { acid }\end{array}$ & Triglyceride \\
\hline $9: 0$ & n.d. & n.d. & 0.1 & tr. \\
\hline 10:0 & n.d. & n.d. & tr. & tr. \\
\hline $12: 0$ & tr. & n.d. & 0.1 & tr. \\
\hline $13: 0$ & 0.1 & 0.3 & n.d. & tr. \\
\hline $14: 0$ & 1.8 & 1.4 & 1.2 & 2.0 \\
\hline $15: 0$ & 1.7 & 2.4 & 0.7 & 0.9 \\
\hline $16: 0$ & 38.2 & 13.0 & 16.5 & 17.9 \\
\hline $17: 0$ & 0.9 & 0.9 & 0.3 & 0.8 \\
\hline $18: 0$ & 0.8 & 1.5 & 1.0 & 0.6 \\
\hline $20: 0$ & tr. & n.d. & n.d. & tr. \\
\hline $22: 0$ & tr. & n.d. & 0.1 & 0.1 \\
\hline $24: 0$ & 0.1 & n.d. & 0.2 & 0.1 \\
\hline Sum saturated & 43.6 & 19.4 & 20.3 & 22.3 \\
\hline Trans 16:1 & tr. & n.d. & n.d. & n.d. \\
\hline Trans 18:1 $n^{-9}$ & $\operatorname{tr}$. & n.d. & n.d. & tr. \\
\hline Trans 18:2 & 0.1 & n.d. & 0.1 & tr. \\
\hline Sum trans & 0.1 & 0.0 & 0.1 & 0.0 \\
\hline $12: 1$ & $\operatorname{tr}$. & n.d. & n.d. & tr. \\
\hline $13: 1$ & $\operatorname{tr}$. & 0.1 & n.d. & n.d. \\
\hline $14: 1$ & n.d. & 0.1 & n.d. & $\operatorname{tr}$ \\
\hline $16: 1 n-9$ & 0.2 & 0.3 & 0.3 & 0.2 \\
\hline $16: 1 n-7$ & 26.8 & 45.5 & 31.0 & 57.6 \\
\hline $17: 1$ & 0.1 & 0.2 & n.d. & 0.3 \\
\hline $18: 1 n-9$ & 1.6 & 1.6 & 1.7 & 1.1 \\
\hline $18: 1 n-7$ & 1.1 & 1.0 & 1.1 & 0.8 \\
\hline 19:1 & tr. & n.d. & n.d. & tr. \\
\hline $20: 1 n-11$ & n.d. & n.d. & n.d. & tr. \\
\hline $22: 1 n-11$ & 0.6 & 0.5 & 0.5 & 0.3 \\
\hline $22: 1 n-9$ & n.d. & n.d. & n.d. & tr. \\
\hline $24: 1 n-9$ & n.d. & n.d. & n.d. & tr. \\
\hline Sum MUFA & 30.5 & 49.3 & 34.5 & 60.3 \\
\hline $18: 2 n-9$ & 1.1 & 1.0 & 0.4 & 0.6 \\
\hline $20: 2 n-9$ & tr. & n.d. & n.d. & tr. \\
\hline $20: 3 n-9$ & tr. & n.d. & n.d. & tr. \\
\hline Sum $n-9$ & 1.1 & 1.0 & 0.4 & 0.7 \\
\hline $18: 2 n-6$ & 0.8 & 0.6 & 0.7 & 0.2 \\
\hline $18: 3 n-6$ & 0.7 & 0.5 & 0.2 & 0.3 \\
\hline $20: 3 n-6$ & tr. & n.d. & n.d. & tr. \\
\hline $20: 4 n-6$ & 0.1 & 0.1 & 0.2 & 0.1 \\
\hline $22: 2 n-6$ & n.d. & n.d. & n.d. & tr. \\
\hline $22: 5 n-6$ & 1.7 & 3.8 & 2.5 & 0.4 \\
\hline Sum $n-6$ & 3.3 & 5.1 & 3.7 & 1.0 \\
\hline $16: 2 n-3$ & 1.8 & 3.3 & 0.2 & 0.4 \\
\hline $18: 3 n-3$ & 0.1 & 0.2 & n.d. & tr. \\
\hline $18: 4 n-3$ & 1.9 & 1.4 & 0.5 & 0.9 \\
\hline $20: 5 n-3$ & 15.8 & 17.8 & 38.0 & 13.9 \\
\hline
\end{tabular}

Table 2 (continued)

\begin{tabular}{lllll}
\hline & Phospholipid & Sterol & $\begin{array}{l}\text { Free fatty } \\
\text { acid }\end{array}$ & Triglyceride \\
\hline $22: 5 n-3$ & tr. & n.d. & n.d. & tr. \\
$22: 6 n-3$ & 1.8 & 2.7 & 2.2 & 0.5 \\
Sum $n-3$ & 21.4 & 25.3 & 41.0 & 15.7 \\
Sum PUFA & 25.7 & 31.3 & 45.1 & 17.3 \\
\hline
\end{tabular}

Biomass cultivated in a 250-mL Erlenmeyer flask containing $100 \mathrm{~mL}$ media and agitated on an orbital mixer at $100 \mathrm{rpm}$

n.d. not detected, tr. trace, MUFA monounsaturated fatty acid, PUFA polyunsaturated fatty acid

Tukey's test, where appropriate. Equality of variance was checked using the modified Levene procedure.

\section{Results}

Proximate biochemical composition and fatty acid profile

Cyclotella cryptica cells were harvested during the early stationary phase of growth. The onset of the stationary phase of growth was caused by a depletion of sodium metasilicate (data not shown). The proximate composition of the harvested biomass is shown in Table 1. The phospholipids, sterols, free fatty acids and triglycerides were extracted from C. cryptica and separated by TLC. Only a minor quantity of the cholesterol ester class was detected and consequently could not be analysed. The fatty acid composition of each lipid class is shown in Table 2 . The major fatty acids in each lipid class are palmitic acid (16:0), palmitoleic acid (16:1 n-7) and EPA (20:5 n-3).

Agitation and aeration

Cyclotella cryptica was cultivated under a variety of heterotrophic growth conditions and was scaled up to a $16-\mathrm{L}$ working volume. The maximum specific growth rates and dry weights at harvest are shown in Table 3. The maximum specific growth rate was not significantly affected $(P>0.05)$ by the rate of agitation within the range of 100 to $160 \mathrm{rpm}$. Agitation rates above $160 \mathrm{rpm}$ could not be undertaken with the available equipment. Minimal growth occurred when the flasks were manually shaken twice a day $(0 \mathrm{rpm})$. The rate of aeration significantly affected $(P>0.05)$ the maximum specific growth rate. The maximum specific growth rate was higher when aerations rates were within the range of 0.44 to $1.07 \mathrm{v} / \mathrm{v} / \mathrm{min}$, as compared to $0.28 \mathrm{v} / \mathrm{v} / \mathrm{min}$. There was no significant 
Table 3 Maximum specific growth rate of Cyclotella cryptica and dry weight at harvest under heterotrophic growth conditions $(n=3$, unless otherwise specified)

\begin{tabular}{|c|c|c|c|}
\hline Cultivation condition & Maximum specific growth rate $\left(\mathrm{h}^{-1}\right)$ & Dry weight at harvest $\left(\mathrm{g} \mathrm{L}^{-1}\right)$ & Duration of growth (days) \\
\hline \multicolumn{4}{|l|}{$250 \mathrm{~mL}$ Erlenmeyer flasks } \\
\hline $0 \mathrm{rpm}$, no aeration & $0.007 \pm 0.003$ & $0.17 \pm 0.01$ & 3 \\
\hline $100 \mathrm{rpm}$, no aeration & $0.052 \pm 0.000$ & $1.33 \pm 0.04$ & 3 \\
\hline $115 \mathrm{rpm}$, no aeration & $0.050 \pm 0.001$ & $1.28 \pm 0.01$ & 3 \\
\hline $130 \mathrm{rpm}$, no aeration & $0.051 \pm 0.001$ & $1.36 \pm 0.08$ & 3 \\
\hline $145 \mathrm{rpm}$, no aeration & $0.051 \pm 0.002$ & $1.29 \pm 0.18$ & 3 \\
\hline $160 \mathrm{rpm}$, no aeration & $0.053 \pm 0.002$ & $1.39 \pm 0.02$ & 3 \\
\hline \multicolumn{4}{|l|}{$500 \mathrm{~mL}$ Schott bottles } \\
\hline $0 \mathrm{rpm}, 0.28 v / v / \mathrm{min}$ & $0.026 \pm 0.000$ & $0.81 \pm 0.06$ & 4 \\
\hline $0 \mathrm{rpm}, 0.44 v / v / \mathrm{min}^{\mathrm{a}}$ & $0.030 \pm 0.001$ & $1.09 \pm 0.126$ & 4 \\
\hline $0 \mathrm{rpm}, 1.07 v / v / \mathrm{min}^{\mathrm{a}}$ & $0.031 \pm 0.000$ & $1.01 \pm 0.11$ & 4 \\
\hline \multicolumn{4}{|l|}{19 L carboys } \\
\hline $0 \mathrm{rpm}, 0.25 v / v / \mathrm{min}^{\mathrm{a}}$ & $0.025 \pm 0.002$ & $2.11 \pm 0.18$ & 12 \\
\hline
\end{tabular}

difference $(P>0.05)$ in the maximum specific growth rate when the aeration rate was $0.44 \mathrm{v} / \mathrm{v} / \mathrm{min}$ or $1.07 \mathrm{v} / \mathrm{v} / \mathrm{min}$. The $C$. cryptica cells remained uniformly suspended within the culture media under all culture conditions except when mixing was absent (i.e. manually shaken flasks). Viability measurements throughout the growth period showed that the $C$. cryptica cells remained viable in spite of the varied culture conditions (data not shown). At the lowest aeration rate $(0.25-0.28 v / v / \mathrm{min})$, the maximum specific growth rate was not significantly affected $(P>0.05)$ by the culture volume and consequently the heterotrophic cultivation of $C$. cryptica was successfully scaled-up from $400 \mathrm{~mL}$ to $16 \mathrm{~L}$ without an observed decrease in the maximum specific growth rate.

\section{Discussion}

The continuous cultivation of microalgal biomass is a method which is frequently used in aquaculture facilities. This mode of cultivation is beneficial as the microalgal biomass can be continuously harvested whilst maintaining the biomass in the exponential growth phase and minimising rapid changes in biochemical composition and nutritional valve. For these reasons, C. cryptica cells used in this study were harvested after they entered the early stationary growth phase. This ensured that sufficient biomass was produced and that the fatty acid profile would be similar to that of the exponential growth phase. The onset of the stationary phase was caused by silicon deficiency. Silicon is often a limiting nutrient for many diatom species as they require silicon to form their silicified cell walls. Silicon deficiency has been shown to induce lipid accumulation in a number of diatoms, including C. cryptica (Roessler 1988a), and this may have altered the proximate biochemical composition.

Despite the heterotrophic growth, the proximate biochemical composition outlined in Table 1 is comparable to the values reported under photoautotrophic conditions. This contradicts the generalised belief that lipid content is markedly reduced under heterotrophic conditions (Borowitzka 1997) and enforces that cell metabolism responses are often species specific and should be studied individually. Furthermore, the major fatty acids synthesised under heterotrophic growth are similar to that of photoautotrophic reports (Kates and Volcani 1966; Roessler 1988b) with the exception that hexadecatrienoic acid $(16: 3 n-3)$ was not identified. $C$. cryptica was capable of synthesising EPA and DHA under heterotrophic growth conditions. While EPA and DHA are essential fatty acids for bivalves, the reported fatty acid composition is qualitative in nature. Before the nutritional value of $C$. cryptica can be estimated, a detailed quantitative analysis should be undertaken.

There is a possibility that the harvested cells contained residual glucose and the reported carbohydrate level could be overestimated and should be viewed with care. The high ash content shown in Table 1 is typical of many diatom species due to their silicon-based frustules. Further optimisation of the culture and environmental conditions may reduce the ash content, as faster dividing cells have thinner frustules (Lewin and Guillard 1963). C. cryptica has been reported to have a specific growth rate of $0.138 \mathrm{~h}^{-1}$ (Werner 1977), but the ash content was not reported.

Aeration and agitation are important parameters to ensure optimal growth and productivity of microalgal 
cells. The rates of agitation and aeration were investigated separately as combining agitation and aeration can have an increased detrimental effect on the growth of microalgae than with either mechanism alone (Yang and Wang 1992; Joshi et al. 1996). The effect of aeration on the maximum specific growth rate of $C$. cryptica was investigated. While the optimal aeration rate remains unknown, the higher aeration rates $(0.44 \mathrm{v} / \mathrm{v} / \mathrm{min}$ and $1.07 \mathrm{v} / \mathrm{v} / \mathrm{min}$ ) increased the maximum specific growth rate. The optimal aeration rate under heterotrophic cultivation would be dependent on the biological oxygen demand (biomass concentration and metabolic rate) of C. cryptica. While the range of aeration rates was narrow, a maximum aeration rate of $1 \mathrm{v} / \mathrm{v} / \mathrm{min}$ was set as it is typical in the cultivation of other microorganisms. Future investigations should also monitor the concentration of dissolved oxygen in the growth media.

The maximum specific growth rate was higher in the agitated vessels than in the aerated vessels. However, the agitation mechanism used (placing the cultivation vessel on an orbital mixer) is not suitable for large-scale cultivation systems. Mechanical agitators are typical in large cultivation systems; however, the sterility requirements of the culture media necessitate that the mechanical seals surrounding the agitator shaft are often complex and expensive, and therefore, mechanical agitators are not suited to low-cost operations. Continuous recirculation of the culture media can also be used to provide the agitation; however, this adds to the complexity of the cultivation process, and the response of the microalgal cells to the shear generated within a recirculation system is unknown. Consequently, aeration is likely to be the preferred method of mixing, and many existing microalgal cultivation systems utilise bubble-column reactors.

In this investigation, aeration was achieved by pumping filtered air through an in-house sparger. Spargers were used as, for a given air flow rate, they emit a larger number of smaller bubbles than a capillary tube, which emits a smaller number of larger bubbles. The smaller bubbles provide a higher surface area per unit volume, and this should improve the mass and energy transfer rates. However, cell damage primarily occurs at the culture media-air interface when the bubble film ruptures (Joshi et al. 1996; Mazzuca Sobezuk et al. 2006). Consequently, the microalgal growth rate and cell viability will depend on the bubble size, bubble frequency and the shear tolerance of the individual microalgal cells.

Rocha et al. (2003) investigated the effect of aeration by sparging and capillary on the growth of Nannochloropsis gaditana. The authors reported that $N$. gaditana responded better when air was supplied via capillary compared to the sparger. However, no actual information was presented on bubble size or shear rates.
This paper has investigated the effects of agitation and aeration on the specific growth rate and cell viability of heterotrophically cultivated C. cryptica. Ultimately, aeration and/or agitation rates should be sufficient to provide adequate mixing, whilst not inhibiting growth or causing cell damage or death by lysis. No critical or detrimental growth conditions were uncovered. In order to improve the productivity of large-scale cultivation systems, future investigations should quantify the critical shear stresses for different microalgae species. In addition, agitation and aeration can affect the biochemical composition of microalgae cells, and future research should investigate the effect of aeration rates on the biochemical composition of $C$. cryptica. Whilst the investigation was preliminary in nature, this paper has reported the growth rate, proximate biochemical composition and fatty acid profile of $C$. cryptica under heterotrophic growth conditions. It was outside the scope of this study to determine if the nutritional value of C. cryptica could be enhanced by heterotrophic cultivation. In order to be nutritionally sufficient, microalgal biomass must supply a balanced mixture of nutrients that matches the nutritional requirements of the target organism. More studies are needed for optimisation of the culture medium and environmental conditions associated with the heterotrophic growth and resulting nutritional value of $C$. cryptica. Further research may show that consistent and high-quality biomass can be economically produced and used as an alternative feed for bivalve spat.

Acknowledgements The authors would wish to thank Mr. Xianzhe Lim (School of Chemical Engineering, The University of Adelaide, Australia) for his assistance, the Child Nutrition Research Centre (Flinders Medical Centre, Australia) for the fatty acid analysis and the School of Molecular and Biomedical Sciences (The University of Adelaide, Australia) for allowing the use of departmental facilities.

\section{References}

ASTM E-1755 (1995) Standard test method for ash in biomass. ASTM International

Beherns PW (2005) Photobioreactors and fermentors: the light and dark sides of growing algae. In: Anderson RA (ed) Algal culturing techniques. Elsevier Academic, NY, pp 189-203

Blank C, Neumann MA, Makrides M, Gibson RA (2002) Optimizing DHA levels in piglets by lowering the linoleic acid to alphalinolenic acid ratio. J Lipid Res 43:1537-1543. doi:10.1194/jlr. M200152-JLR200

Borowitzka MA (1997) Microalgae for aquaculture: opportunities and constraints. J Appl Phycol 9:393-401. doi:10.1023/ A: 1007921728300

Brown MR (2002) Nutritional value of microalgae for aquaculture. In: Cruz-Suarez LE, Ricque-Marie D, Tapia-Salazar M, GaxiolaCortes MG, Simones N (eds) Avances en Nutrición Acuícola VI, Memorias del VI Simposium Internacional de Nutrición Acuícola. Mexico. pp 281-292 
Brown MR, Jeffrey SW, Garland CD (1989) Nutritional aspects of microalgae used in mariculture: a literature review. CSIRO Marine Laboratories Report No. 205. Australia. 41 pp

Chen F (1996) High cell density culture of microalgae in heterotrophic growth. Trends Biotechnol 14:421-426. doi:10.1016/0167-7799 (96)10060-3

Crippen RW, Perrier JL (1974) The use of neutral red and Evans blue for live-dead determinations of marine plankton. Stain Technol 49:97-104

Darley WM (1977) Biochemical composition. In: Werner D (ed) The biology of diatoms. Blackwell, Oxford, pp 189-223

De Pauw N, Morales J, Persoone G (1984) Mass culture of microalgae in aquaculture systems - progress and constraints. Hydrobiologia 116-117:121-134. doi:10.1007/BF00027650

Dorsey TE, McDonald PW, Roels OA (1978) Measurements of phytoplankton-protein content with the heated biuret-folin assay. J Phycol 14:167-171. doi:10.1111/j.1529-8817.1978.tb02443.x

Dubois M, Gilles KA, Hamilton JK, Rebers PA, Smith F (1956) Colorimetric method for determination of sugars and related substances. Anal Chem 28:350-356. doi:10.1021/ac60111a017

Duerr EO, Molnar A, Sato V (1998) Cultured microalgae as aquaculture feeds. J Mar Biotechnol 6:65-70

Dunstan GA, Volkman JK, Jeffrey SW, Barrett SM (1992) Biochemical composition of microalgae from the green algal classes Chlorophyceae and Prasinophyceae. 2. Lipid classes and fatty acids. J Exp Mar Biol Ecol 161:115-134. doi:10.1016/0022-0981 (92) $90193-\mathrm{E}$

Fisheries FAO, Department A (2007) The state of world fisheries and aquaculture 2006. Food and Agriculture Organization of the United Nations, Rome, p 164

Gladue RM, Maxey JE (1994) Microalgal feeds for aquaculture. J Appl Phycol 6:131-141. doi:10.1007/BF02186067

Hansen HP, Koroleff F (1999) Determination of dissolved inorganic silicate. In: Grasshoff K, Kremling K, Ehrhardt M (eds) Methods of seawater analysis. Wiley, Weinheim, pp 193-197

Harel M, Koven W, Lein I, Bar Y, Behrens P, Stubblefield J, Zohar Y, Place AR (2002) Advanced DHA, EPA and ArA enrichment materials for marine aquaculture using single cell heterotrophs. Aquaculture 213:347-362. doi:10.1016/S0044-8486(02)00047-9

Heasman M, Diemer J, O'Connor W, Sushames T, Foulkes L (2002) Development of extended shelf-life microalgae concentrate diets harvested by centrifugation for bivalve molluscs - a summary. Aquacult Res 31:637-659. doi:10.1046/j.1365-2109.2000. 00492.x

Hellebust JA (1971) Kinetics of glucose transport and growth of Cyclotella cryptica Reimann, Lewin and Guillard. J Phycol 7:1-4

Joshi JB, Elias CB, Patole MS (1996) Role of hydrodynamic shear in the cultivation of animal, plant and microbial cells.
Chem Eng J Biochem Eng J 62:121-141. doi:10.1016/09230467(95)03062-X

Kates M, Volcani BE (1966) Lipid components of diatoms. Biochim Biophys Acta 116:264-278

Laing I, Millican PF (1992) Indoor nursery cultivation of juvenile bivalve molluscs using diets of dried algae. Aquaculture 102:231-243. doi:10.1016/0044-8486(92)90151-A

Lewin JC, Guillard RRL (1963) Diatoms. Annu Rev Microbiol 17:373-414. doi:10.1146/annurev.mi.17.100163.002105

Loosanoff VL, Davis HC (1963) Rearing of bivalve mollusks. Adv Mar Biol 1:1-136. doi:10.1016/S0065-2881(08)60257-6

Mazzuca Sobezuk T, García Camacho F, Molina Grima E, Chisti Y (2006) Effects of agitation on the microalgae Phaeodactylum tricornutum and Porphyridium cruentum. Bioprocess Biosyst Eng 28:243-250. doi:10.1007/s00449-005-0030-3

Miller GL (1959) Use of dinitrosalicylic acid reagent for determination of reducing sugar. Anal Chem 31:426-428. doi:10.1021/ ac60147a030

Renaud SM, Parry DL (1994) Microalgae for use in tropical aquaculture II: effect of salinity on growth, gross chemical composition and fatty acid composition of three species of marine microalgae. J Appl Phycol 6:347-356. doi:10.1007/BF02181949

Rocha JMS, Garica JEC, Henriques MHF (2003) Growth aspects of the marine microalga Nannochloropsis gaditana. Biomol Eng 20:237-242. doi:10.1016/S1389-0344(03)00061-3

Roessler PG (1988a) Changes in the activities of various lipid and carbohydrate biosynthetic enzymes in the diatom Cyclotella cryptica in response to silicon deficiency. Arch Biochem Biophys 267:521-528. doi:10.1016/0003-9861(88)90059-8

Roessler PG (1988b) Effects of silicon deficiency on lipid composition and metabolism in the diatom Cyclotella cryptica. J Phycol 24:394-400

Webb KL, Chu FE (1983) Phytoplankton as a food source for bivalve larvae. In: Pruder GD, Langdon C, Conklin D (eds) Second international conference on aquaculture nutrition: biochemical and physiological approaches to shellfish nutrition. Louisiana State University Press, Baton Rouge, pp 272 291

Wen ZY, Chen F (2003) Heterotrophic production of eicosapentaenoic acid by microalgae. Biotechnol Adv 21:273-294. doi:10.1016/ S0734-9750(03)00051-X

Werner D (1977) Silicate metabolism. In: Werner D (ed) The biology of diatoms. Blackwell, Oxford, pp 110-149

White AW (1974) Growth of two facultatively heterotrophic marine centric diatoms. J Phycol 10:292-300

Yang JD, Wang NS (1992) Cell inactivation in the presence of sparging and mechanical agitation. Biotechnol Bioeng 40:806816. doi:10.1002/bit.260400708 